\title{
Cryopreservation of Pyrostegia venusta (Ker Gawl.) Miers seeds
}

\author{
(D) Antonieta Nassif Salomão1, (D) Izulmé Rita Imaculada Santos ${ }^{1,2}$ e (D) Solange Carvalho Barrios Roveri José1
}

Received: 21.11.2019; accepted: 29.04.2020

Como citar: Salomão, A.N., Santos, I.R.I., \& José, S.C.B.R. 2020. Cryopreservation of Pyrostegia venusta (Ker Gawl.) Miers seeds. Hoehnea 47: e1042019. http://dx.doi.org/10.1590/2236-8906-104/2019

Abstract - (Cryopreservation of Pyrostegia venusta (Ker Gawl.) Miers seeds). Seeds of Pyrostegia venusta (Ker Gawl.) Miers) were desiccated at $25^{\circ} \mathrm{C}$ on silica gel for $0 \mathrm{~h}\left(\mathrm{~T}_{0}\right), 7 \mathrm{~h}\left(\mathrm{~T}_{1}\right)$ and $24 \mathrm{~h}\left(\mathrm{~T}_{2}\right)$, reaching moisture contents of $6.5 \%, 4.4 \%$ and $3.8 \%$, respectively. Seeds were frozen rapidly in liquid nitrogen $(+\mathrm{LN})$ at $-263{ }^{\circ} \mathrm{C} . \mathrm{min} \cdot{ }^{-1}$ and after $72 \mathrm{~h}$, they were thawed slowly at room temperature $\left(25 \pm 2{ }^{\circ} \mathrm{C}\right)$ at a speed of $5{ }^{\circ} \mathrm{C} \cdot \mathrm{min} .{ }^{-1}$. Seed germinability evaluation before (-LN) and after freezing $(+\mathrm{LN})$ was conducted at $25^{\circ} \mathrm{C}$, on paper roll substrate, and germinated at $16 \mathrm{hrs} \mathrm{light/} / 8 \mathrm{hrs}$ dark, normal seedling counts for 38 days. The germinative percentages were $88 \%\left(\mathrm{~T}_{0}-\mathrm{LN}\right), 98 \%\left(\mathrm{~T}_{0}+\mathrm{LN}\right), 61 \%\left(\mathrm{~T}_{1}-\mathrm{LN}\right), 95 \%\left(\mathrm{~T}_{1}+\mathrm{LN}\right), 78 \%\left(\mathrm{~T}_{2}-\right.$ $\mathrm{LN})$ and $89 \%\left(\mathrm{~T}_{2}+\mathrm{LN}\right)$. Mean days for seedling formation were $23\left(\mathrm{~T}_{0}-\mathrm{LN}\right), 22\left(\mathrm{~T}_{1}-\mathrm{LN}\right.$ and $\left.\mathrm{T}_{2}-\mathrm{LN}\right)$ and 30 days for seeds exposed to LN. Fast freezing, slow thawing, and the three tested moisture contents, were suitable for cryopreservation of Pyrostegia venusta seeds.

Keywords: desiccation, germination, orange trumpet vine

Resumo - (Criopreservação de sementes de Pyrostegia venusta (Ker Gawl.) Miers). Sementes de Pyrostegia venusta (Ker Gawl.) Miers) foram dessecadas a $25^{\circ} \mathrm{C}$, sobre sílica gel por $0 \mathrm{~h}\left(\mathrm{~T}_{0}\right), 7 \mathrm{~h}\left(\mathrm{~T}_{1}\right)$ e $24 \mathrm{~h}\left(\mathrm{~T}_{2}\right)$, atingindo teores de água de $6,5 \%$, $4,4 \%$ e $3,8 \%$, respectivamente. As sementes foram congeladas em nitrogênio líquido (+NL), a $-263{ }^{\circ} \mathrm{C} \cdot \mathrm{min} .{ }^{-1}$ e após $72 \mathrm{~h}$ foi descongeladas à temperatura ambiente de $25 \pm 2{ }^{\circ} \mathrm{C}$, a $5^{\circ} \mathrm{C}$.min..$^{-1}$. A avaliação da germinabilidade das sementes antes (-NL) e após congelamento ( $+\mathrm{NL}$ ) foi conduzida a $25^{\circ} \mathrm{C}$, substrato rolo de papel, fotoperíodo $16 \mathrm{~h}$ luz/8 h escuro e contagens de plântulas normais por 38 dias. Os percentuais germinativos foram de 88\% $\left(\mathrm{T}_{0}-\mathrm{NL}\right), 98 \%\left(\mathrm{~T}_{0}+\mathrm{NL}\right), 61 \%\left(\mathrm{~T}_{1}-\mathrm{NL}\right), 95 \%$ $\left(\mathrm{T}_{1}+\mathrm{NL}\right), 78 \%\left(\mathrm{~T}_{2}-\mathrm{NL}\right)$ e de $89 \%\left(\mathrm{~T}_{2}+\mathrm{NL}\right)$. Os tempos médios para a formação de plântulas foram de $23\left(\mathrm{~T}_{0}-\mathrm{NL}\right), 22\left(\mathrm{~T}_{1}-\mathrm{NL}\right.$ e $\mathrm{T}_{2}-\mathrm{NL}$ ) e de 30 dias para as sementes expostas ao NL. O congelamento rápido, o descongelamento lento e os três teores de água testados foram adequados para a criopreservação de sementes de Pyrostegia venusta.

Palavras-chave: cipó de São João, dessecação, germinação

\section{Introduction}

Lianescent, herbaceous, shrub and arboreal species of the Bignoniaceae family are widely distributed throughout South America (Ortolani 2007; Camarinha et al. 2015). Among the lianescent species of this botanical family, Pyrostegia venusta (Ker Gawl.) Miers, orange trumpet vine, is a Brazilian native plant found in distinct vegetation formations in all regions of Brazil (Hortenci et al. 2018). Although $P$. venusta is generally cited as an invasive plant and weed in pastures, the species is a popular ornamental, cultivated for landscaping due to its lush inflorescences that hold striking orange tubular flowers (Oliveira \& Wendling 2013, Online Compendium Gerson Luiz Lopes 2018, Plantamed 2018). In Brazilian folk medicine, aerial parts and flowers of the plant are used in infusions or decoctions and administered orally as a general tonic, as well as for the treatment of diarrhea, vitiligo, cough and common infectious diseases of the respiratory system such as bronchitis, flu and cold (Ferreira et al. 2000, Mostafa et al. 2013). Pharmacological studies, analyzing hidroethylic extracts of flowers, aerial parts and roots successfully isolated biologically active compounds oleanolic acid, acacetin 7-O- $\beta$-glucopyranoside and $\beta$-sitosterol, with anti-inflammatory, antitumor,

1 Embrapa Recursos Genéticos e Biotecnologia, Parque Estação Biológica, Avenida W5 Norte (final), s/n, 70770-917 Brasília, DF, Brasil 2 Corresponding author: izulme.santos@embrapa.br 
antioxidant, antimicrobial and anti-HIV, antiallergic and immunomodulatory properties (Veloso et al. 2010, Mostafa et al. 2013, Figueiredo et al. 2014, Moreira et al. 2015). P. venusta is an alternative source for in vitro production of these bioactive phenolic compounds (Braga et al. 2015).

Due to its multiple uses, conservation of $P$. venusta germplasm is considered a priority in order to ensure availability of the species' genetic variability to meet demands of current and future research programs in pharmacology, bio products production and genetic improvement. Conservation of seeds in gene banks in cold rooms is the conventional approach for plant germplasm conservation. However, one of the physiological characteristics of seeds of species of the Bignoniaceae family is that they are short-lived under storage (Aguiar 2010, Tresena et al. 2010, Martins et al. 2014). This is generally attributed to the instability of lipid compounds present in the bilobed cotyledons of the seeds (Gabrielli 1988, Renó et al. 2007). In addition, during storage, shorter seed longevity can be associated with oxidative stress of macromolecules such as nucleic acid, proteins and lipids (Sano et al. 2016). In the particular case of $P$. venusta, studies showed that seeds stored at room temperature, at $10^{\circ} \mathrm{C}$ and $4^{\circ} \mathrm{C}$ maintained viability for short periods of time (Gabrielli 1988, Rossatto \& Kolb 2010). However, there are no studies on these seed's viability after storage at subzero temperatures such as $-20^{\circ} \mathrm{C}$, in a conventional gene bank, or at $-196^{\circ} \mathrm{C}$, in a cryobank. Considering that seeds with lipid reserves, such as those of $P$. venusta, present viability loss when stored in cold rooms at $-20^{\circ} \mathrm{C}$, the most promising approach to ensure long-term conservation of this species germplasm is cryopreservation in liquid nitrogen, (Michalak et al. 2013). Cryopreservation includes a range of techniques for freezing and storing biological material in liquid nitrogen, at $-196^{\circ} \mathrm{C}$ (Panis 2019). These techniques are currently the most effective approach for long-term conservation of plant germplasm, because cryopreservation requires minimal storage space, labor and maintenance, all the while preserving the integrity and preventing aging of stored samples for unlimited periods (Panis 2019). Cryopreservation techniques are now used in an increasing number of gene banks and research facilities around the world (Kalaiselvi et al. 2017, Panis 2019).

Plant cells contain high amounts of water and are not inherently freeze-tolerant, so they are extremely susceptible to freezing injury. This is a critical point in the development of a cryopreservation protocol, because plant structures with high levels of cellular water will be injured during cryopreservation due to crystallization of the water present in the cell into ice upon exposure to freezing temperatures (Mazur 1984). Therefore, plant cells dehydration prior to exposure to liquid nitrogen is essential to protect them from damage caused by intracellular ice formation.

The objective of this work was to establish a procedure for cryopreservation of Pyrostegia venusta seeds in liquid nitrogen, at $-196^{\circ} \mathrm{C}$.

\section{Materials and methods}

Mature semi-open Pyrostegia venusta septicidal capsules were harvested in September of 2019 (three months after flowering) from 15 plants growing at Embrapa Genetic Resources and Biotechnology experimental field, located in

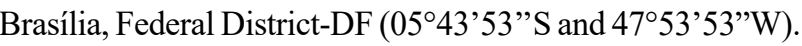
The experiments were conducted at the Seed Laboratory and the Plant Cryobiology Laboratory of this institution. The seeds, extracted manually from the capsules, were cleaned, selected, homogenized and divided into three samples of 240 seeds. The samples were desiccated with blue indicator silica gel ( $4 \mathrm{~g}$ silica/1g seed) for $0 \mathrm{~h}\left(\mathrm{~T}_{0}\right), 7$ $\mathrm{h}\left(\mathrm{T}_{1}\right)$ and $24 \mathrm{~h}\left(\mathrm{~T}_{2}\right)$, at a constant temperature of $25^{\circ} \mathrm{C}$, in a Percival germinator. Seed moisture contents $(\mathrm{mc})$ after each desiccation period were determined by the gravityconvection method (Brazil, 2009) Four repetitions of ten seeds were used for the determination of the $\mathrm{mc}$, and the results were expressed as average percentages of seed fresh weight.

Following desiccation, each sample (200 seeds) were divided into two subsamples (100 seeds each), one for freezing in LN and another to be used as control. Seeds were packed in aluminized bag, sealed with parafilm and identified with the respective desiccation period. For freezing in LN, the packets were immersed directly into liquid nitrogen (LN), at $-196{ }^{\circ} \mathrm{C}$, at a cooling rate $-263{ }^{\circ} \mathrm{C} \cdot \mathrm{min} \cdot{ }^{-1}$ (Salomão 2002). After 72 hours, the material was removed from the $\mathrm{LN}$ and kept on the laboratory bench to thaw slowly at room temperature $\left(25 \pm 2{ }^{\circ} \mathrm{C}\right)$, at a cooling rate of approximately $5{ }^{\circ} \mathrm{C} \cdot \mathrm{min}^{-1}$ (Salomão 2002). Control samples (-LN) were maintained in the laboratory bench, at room temperature $\left(25 \pm 2{ }^{\circ} \mathrm{C}\right)$, for $72 \mathrm{hrs}$. After $72 \mathrm{hrs}$, desiccated (- LN) and desiccated and frozen $(+\mathrm{LN})$ seeds were immersed in a commercial neutral detergent solution at $2 \%(\mathrm{v} / \mathrm{v})$ concentration for $5 \mathrm{~min}$, followed by rinsing under running tap water until complete removal of the product. After surface disinfection, germination tests were conducted with four replications of 25 seeds per treatment, on paper roll substrate. This standard germination substrate was prepared by distributing seeds evenly onto two sheets of Germitest ${ }^{\circledR}$ paper moistened with distilled water (volume equivalent to 2.5 times the mass of the dry paper), covering seeds with another sheet of moist paper and then making a roll of the paper sheets containing the seeds. Paper rolls were placed into plastic bags, incubated in a germination chamber set at constant temperature of $25^{\circ} \mathrm{C}$, photoperiod $16 \mathrm{hrs} \mathrm{light}$ provided by eight $40 \mathrm{w}$ fluorescent bulbs and $8 \mathrm{hrs}$ dark, with daily counts of germinated seeds for 38 days. Final results were expressed as percentage of germinated seeds that formed normal seedlings, that is, those presenting the first pair of expanded eophils and the main root.

Mean days for seedling formation were calculated according to Santana \& Ranal 2004: 


$$
\mathrm{M}_{\mathrm{days}}=N_{1} G_{1}+N_{2} G_{2}+\ldots .+N_{\mathrm{n}} G_{\mathrm{n}} / G_{1}+G_{2}+\ldots+G_{\mathrm{n}}
$$

In which:

$N_{1}, N_{2}, \ldots, N_{\mathrm{n}}=$ number of days counted from sowing to observation day. day.

$G_{1}, G_{2, \ldots}, G_{\mathrm{n}}=$ number of seeds germinated on observation

The experimental design was completely randomized with factorial arrangement of three $\mathrm{mc}$ of non-frozen $(-\mathrm{LN})$ and frozen $(+\mathrm{LN})$ seeds. The germination and $\mathrm{M}_{\text {days }}$ data were subjected to analysis of variance (ANOVA), at P $<$ 0.05 , to test for the effects of mc levels and of freezing in liquid nitrogen on the germinability of the seeds. The means of germination percentages were compared by Bonferroni's Multiple Comparison Test, at $\mathrm{P}<0.05$. All data analysis were performed using the statistical program GraphPad Prism (@2017 Graph Pad Software Inc.).

\section{Results and Discussion}

Pyrostegia venusta seeds had an initial mc of $6.5 \%$, which corresponded to the desiccation time $\mathrm{T}_{0}$. This initial value of $\mathrm{mc}$ can be attributed to water loss during maturation drying, a natural phase of seed development, but also to the fact that the capsules were already semi dehiscent by the time they were harvested, which allowed the loss of seed moisture under field conditions. After desiccation on silica gel for seven hrs $\left(\mathrm{T}_{1}\right)$ seeds reached $4.4 \% \mathrm{mc}$, and at the end of $24 \mathrm{hrs}$ of desiccation, seeds reached $\mathrm{mc}$ of $3.8 \%$ $\left(\mathrm{T}_{2}\right)$. The germination percentages of unfrozen $(-\mathrm{LN})$ seeds were $88 \%\left(T_{0}\right), 61 \%\left(T_{1}\right)$ and $78 \%\left(T_{2}\right)$ (Figure 1). Seeds of $\mathrm{T}_{1}$ had lower germination percentage value $(61 \%)$ and it

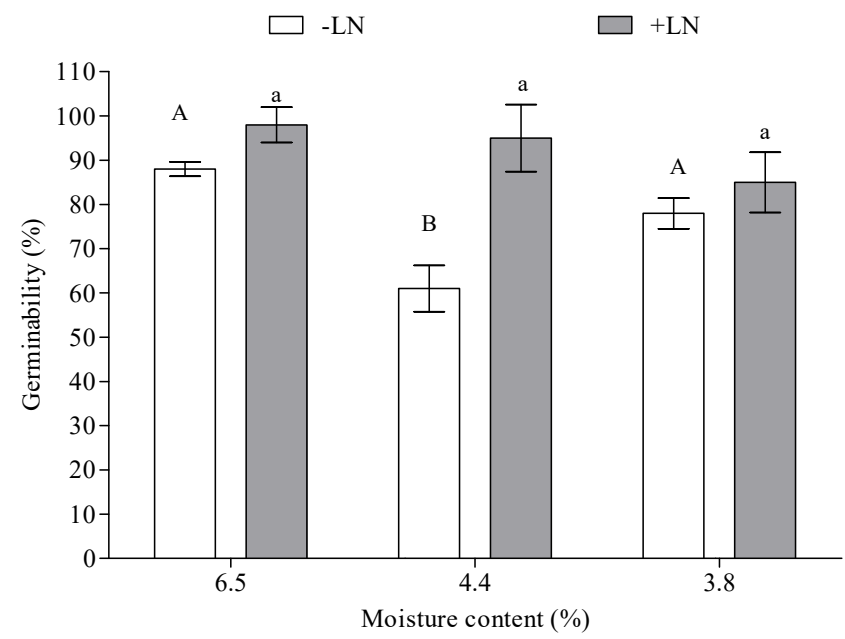

Figure 1. Germination percentages of Pyrostegia venusta (Ker Gawl.) Miers seeds with different moisture contents before (-LN) and after $(+\mathrm{LN})$ liquid nitrogen exposure. The same capital letter $(-\mathrm{LN})$ and the same small letter $(+\mathrm{LN})$ are not significantly different for ANOVA at $\mathrm{P}<0.05$ by Bonferroni's Multiple Comparison Test. Vertical error bars represent $\mathrm{SE}$ of means of four replications $(\mathrm{P}<0.05)$. differed statistically $(\mathrm{P}<0.05)$ from the other germination percentages, $88 \%\left(\mathrm{~T}_{0}\right)$ and $78 \%\left(\mathrm{~T}_{2}\right)$. However, it was observed that $\mathrm{T}_{1}$ had the largest number of empty seeds, which probably contributed to this reduction in germination percentage. Reduction of mc from $6.5 \%\left(\mathrm{~T}_{0}\right)$ to $4.4 \%\left(\mathrm{~T}_{1}\right)$ and $3.8 \%\left(\mathrm{~T}_{2}\right)$ apparently did not have a deleterious effect on seed viability, as evidenced by a low percentage of abnormal seedling formation. Shankaralingappa et al. (2019) reported that seeds of papaya cultivars Akra Prabhath and Akra Surya desiccated to $4.1 \%$ and $4.2 \%$, respectively, maintained initial viability and vigor, while seeds of the cultivar Sunrise solo showed reduced germination after drying to $3.6 \% \mathrm{mc}$, indicating that reduction in me below $4 \%$ was harmful for seeds of this species. Zhang et al. (2019) concluded that desiccation to extreme low moisture contents stabilized longevity of Calocedrus macrolepis seeds stored at room temperature for 5 years, since germination percentages and vigor of seeds desiccated to $2.1 \%$ and $3.0 \% \mathrm{mc}$ were higher than the values obtained for non-dehydrated control seeds $(\mathrm{mc}=7.5 \%)$. However, for some species, the effect of extreme reduction in seed mc below a critical moisture level is unpredictable and might result in mechanical structure changes and deleterious effects on germination and viability (Ballesteros \& Walters, 2011; Colville \& Pritchard, 2019). The mc of the seeds had no significant effect $(\mathrm{P}<0.05)$ on germination values after freezing in LN. However, freezing in $\mathrm{LN}$ at $-196{ }^{\circ} \mathrm{C}$ had a significant enhancing effect $(\mathrm{P}>$ 0.05 ) on the germination performance of $P$. venusta seeds (Figure 1, Table 1). After exposure to LN, germination percentages were, $98 \%\left(\mathrm{~T}_{0}\right), 95 \%\left(\mathrm{~T}_{1}\right), 89 \%\left(\mathrm{~T}_{2}\right)$, values higher than those obtained with desiccated unfrozen seeds (- LN). Seeds of some species develop cracks in the seed coat during immersion in liquid nitrogen, a phenomenon that promote seed germination as they serve as openings for water entry, triguering germination processes (Salomão 2002). Liquid nitrogen exposure has been used in many cases as a dormancy breaking treatment for species with impermeable seed coats (Wu et al. 2017).

Pyrostegia venusta seeds can withstand both desiccation and LN exposure. However, one of the intrinsic characteristics of seeds that can have a detrimental effect on survival after LN freezing is mc. Because of this, the first step in establishing a cryopreservation protocols is to adjust seed $\mathrm{mc}$ to values that prevent freezing damage. Such damage may become cumulative in subsequent steps of the protocol, i.e. thawing and imbibition during seed germination (Pereira et al. 2014, Salomão et al. 2015). One of the approaches to promote cellular dehydration is exposure of plant structures, such as seeds, to silica gel, which will cause controlled loss of water by evaporation (Santos \& Salomão 2017). As shown in Table 1, the variable $\mathrm{mc}$ did not interfere in the germination process of the seeds of $P$. venusta. Unfrozen $(-\mathrm{LN})$ and frozen $(+\mathrm{LN})$ seeds dehydrated on silica gel reaching different $\mathrm{mc}, 6.5 \%\left(\mathrm{~T}_{0}\right)$, 4.4\% $\left(\mathrm{T}_{1}\right)$ and 3.8\% $\left(\mathrm{T}_{2}\right)$ maintained high germinability. 
Despite of the lower germination percentage (61\%) for seeds with $4.4 \%$ mc compared to the other germination values attained by seeds with lower or higher mc, this germination rate is similar to those observed in a study with $P$. venusta seeds treated with germination promoters $\mathrm{KNO}_{3}(2 \%)$ or $\mathrm{GA}_{3}\left(150 \mathrm{mg} . \mathrm{L}^{-1}\right)$, when germination percentages were $62 \%$ and $63.3 \%$, respectively (Scalon et al. 2008, Santos 2016).

Post-seminal phases of seedling development were followed for up to 38 days. Seeds at all three mc germinated promptly and seedling morphology showed normal development with formation of aerial parts and root systems (Figure 2). For control seeds, $M_{\text {days }}$ for normal seedling formation, showing the first pair of expanded eophiles and the main root, were 23 days $\left(\mathrm{T}_{0}-\mathrm{LN}\right)$ and 22 days $\left(\mathrm{T}_{1}-\mathrm{LN}\right.$ and $\left.\mathrm{T}_{2}-\mathrm{LN}\right)$. For frozen seeds $(+\mathrm{LN})$, the $\mathrm{M}_{\text {days }}$ were 30 days for the three mc tested (Table 2).

Freezing and thawing rates, as well as seed mc, are decisive factors for the maintenance of functional and structural integrity of cryopreserved seeds. If inadequate, these factors result in biochemical and biophysical damage that compromise seed survival. The difference between $\mathrm{M}_{\text {days }}$ values for unfrozen $P$. venusta seeds (- $\left.\mathrm{LN}\right)$ and frozen seeds $(+\mathrm{LN})$ was presumably due to cell destabilization due to freezing or thawing process. In this case, longer soaking time was required to activate the cellular repair mechanisms, as well as, for the mobility of nutrients responsible for embryonic axis growth. Results obtained suggest that for cryopreserved seeds longer soaking time contributed not only to the repair of damage, but also to improve the performance of subsequent phases of the germination process, since germination percentages were 98\% $\left(\mathrm{T}_{0}+\mathrm{LN}\right), 95 \%\left(\mathrm{~T}_{1}+\mathrm{LN}\right), 89 \%\left(\mathrm{~T}_{2}+\mathrm{LN}\right)$, without abnormal seedling development (Figure 2). Another factor that probably contributed to these results may have been that LN pressure exerted on the embryo or seed structure (integument, endocarp and others) can induce disruption or a network of cracks, make them less rigid and improve imbibition. Such effects of $\mathrm{LN}$ are beneficial as they allow greater water absorption by seeds, improving germination performance (Jordan et al. 1982, Jitsopakula et al. 2012). However, in seeds of some species there may be greater leakage of solutes through these cracks or by the malleability of tissues. This results in, among other events, slower seedling development, as longer time is required for structural repair, especially of the membranes of the tonoplast and plasmalema (Khanna et al. 2014). A similar pattern was observed in a study with Tabebuia aurea (Silva Manso) Benth and Hook F. ex S. Moore in which seeds frozen in $\mathrm{LN}$ required longer soaking time and absorption of bigger volume of water for seedling formation to occur than unfrozen seeds or seeds frozen at $-20{ }^{\circ} \mathrm{C}$ (Salomão \& Fujichima 2002).

Pyrostegia venusta seeds can be stored for short periods, with reported storage longevity of five months at room temperature, six months at $10^{\circ} \mathrm{C}$, one year when packed in silica gel and more than two years at $4{ }^{\circ} \mathrm{C}$ (Gabrielli 1988, Rossatto \& Kolb 2010, Santos 2016). The loss of germinability, viability and vigor in lipid seeds after storage at low or subzero temperatures may possibly be due to hydrolytic and oxidative rancidity of fatty acids

Table 1. Effect of moisture content (mc) and liquid Nitrogen (LN) exposure on seed germination of Pyrostegia venusta (Ker Gawl.) Miers. ANOVA obtained from variance analysis, $\mathrm{P}<0.05$ level of significance.

\begin{tabular}{lccccc}
\hline Variables & Sum-of-squares & $\begin{array}{c}\text { Degree of } \\
\text { freedom }\end{array}$ & F & P value & $\begin{array}{c}\text { \% of total } \\
\text { variation }\end{array}$ \\
\hline Liquid nitrogen (LN) & 88.17 & 1 & 529.0 & 0.0019 & 99.25 \\
Moisture content (mc) & 0.3333 & 2 & 1.000 & 0.5000 & 0.38 \\
Residual & 0.3333 & 2 & & & \\
\hline
\end{tabular}

Table 2. Mean days for seedling formation from seeds of Pyrostegia venusta (Ker Gawl.) Miers with different moisture contents before $(-\mathrm{LN})$ and after $(+\mathrm{LN})$ liquid nitrogen exposure.

\begin{tabular}{lccc}
\hline \multirow{2}{*}{$\begin{array}{l}\text { Desiccation Duration } \\
(\mathrm{hrs})\end{array}$} & $\begin{array}{c}\text { Moisture content } \\
(\%)\end{array}$ & \multicolumn{2}{c}{ Mean days for seedling formation $\left(\mathrm{M}_{\text {days }}\right)$} \\
\hline $0\left(\mathrm{~T}_{0}\right)$ & 6.5 & $-\mathrm{LN}$ & $+\mathrm{LN}$ \\
$7\left(\mathrm{~T}_{1}\right)$ & 4.4 & $23 \mathrm{~B}$ & $30 \mathrm{~A}$ \\
$24\left(\mathrm{~T}_{2}\right)$ & 3.8 & $22 \mathrm{~B}$ & $30 \mathrm{~A}$ \\
\hline
\end{tabular}

The same capital letter in the column is not significantly different at $\mathrm{P}<0.05$ by variance analysis (ANOVA). 


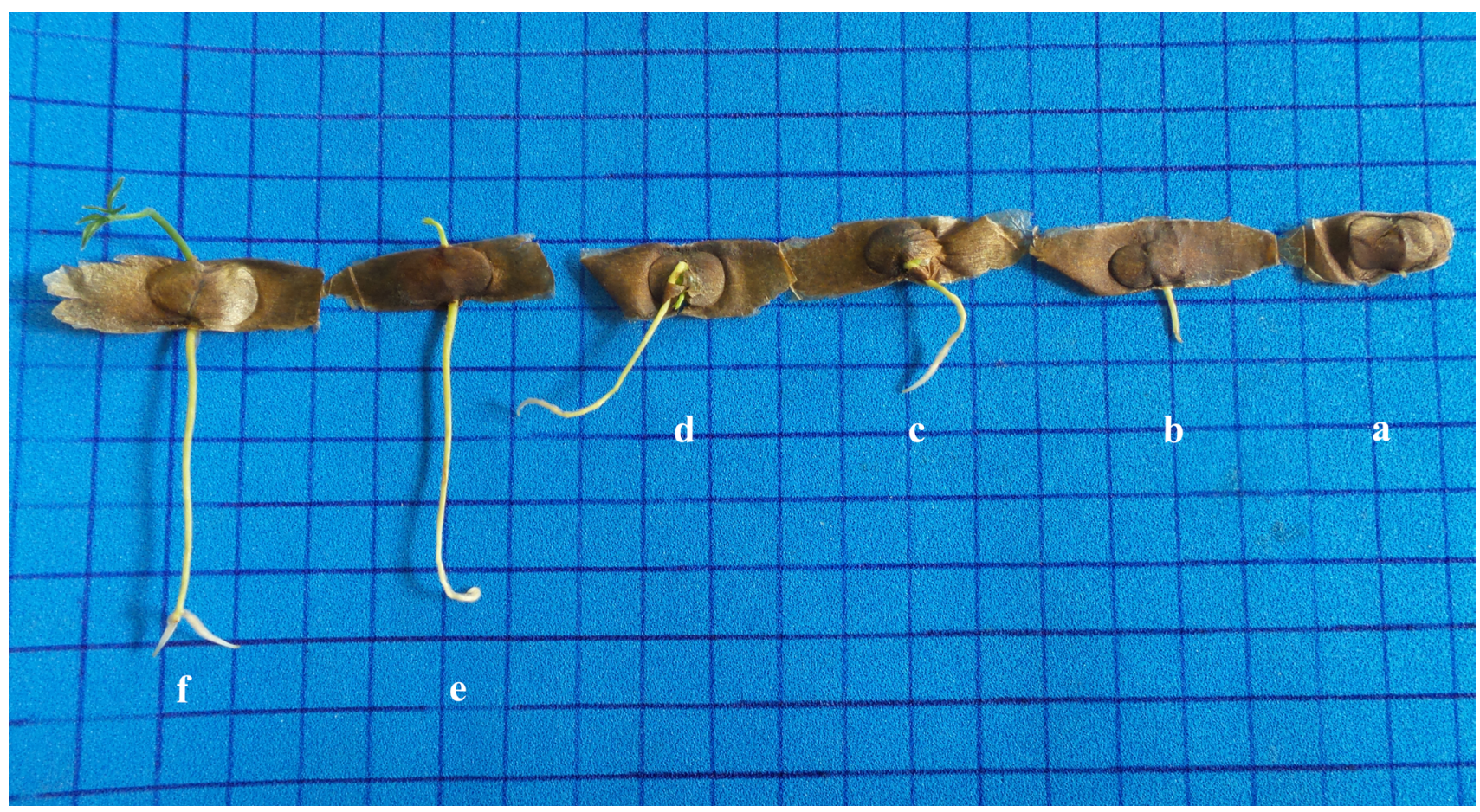

Figure 2. Pyrostegia venusta (Ker Gawl.). Miers post-seminal phases of seedling development. a. radicle protrusion. b-d. radicle development. e. epicotyl emergence. f. first pair of expanded eophils and the main root (scale: square side on the background corresponds to $1 \mathrm{~cm}$ ).

(Chmielarz 2009, Balešević-Tubic et al. 2010). Currently, the recommendations to maintain viability of seeds with short life span and low storability are the conservation using cryogenic methods, at $-196{ }^{\circ} \mathrm{C}$ (Normah et al. 2019, Hay \& Probert 2013). The successful cryopreservation of seeds of several tropical species has been attributed to the adjustment of mc according to the specificity of each species, the use of methods that allow rapid freezing by direct immersion in $\mathrm{LN}$ and slow thawing at room temperature (Santos et al. 2013, Salomão \& Santos 2018). During rapid freezing, there is uniformity of subcellular water cooling and the formation of small intra and extracellular ice crystals, preventing damage by cell dehydration and rupture of cell membranes (González-Arnao et al. 2014). Fast thawing may cause ice crystal formation, biophysical and biochemical changes in lipids and proteins that can result in critical or lethal damage to seeds while slow thawing maintains seed morphophysiological integrity (González-Arnao et al. 2014). Some examples of tropical species that achieved high viability or germination percentages after cryopreservation in $\mathrm{LN}$ are Epidendrum quitensium Rchb.f., E. andressonii Hágsater and Dodson, Passiflora edulis Sims, P. mucronata Lam., P. suberous L., Encholirium magalhaesii L. B. Sm. E. spectabile Martius ex Schultes f., E. subsecundum (Baker) Mez, Magonia pubescens A. St. Hil., Ormosia flava (Ducke) Rudd. Peltogyne confertiflora (Mart. ex Hayne) Benth. and Sparattanthelium tupiniquinorum Mart. (Cerna et al. 2018,
Araújo et al. 2016, Ferrari et al. 2016, Salomão et al. 2015, Tarré et al. 2007).

The results obtained with $P$. venusta seeds after exposure to $\mathrm{LN}$ are compatible with those observed in seeds of other species of the Bignoniaceae family. Liquid nitrogen had a stimulatory effect on germinability for seeds of six species with mc ranging from $4.2 \%$ to $8.5 \%$ and germination percentages before and after exposure to $\mathrm{LN}$ were $68 \%$ - $84 \%$ (Anemopaegma arvense (Vell.) Stellfeld ex de Souza) 88\% 93\% (Handroanthus serratifolius (Vahl) S. Grose), 78 - 89\% (Jacaranda cuspidifolium Mart.), 78\% - 89\% (Tabebuia aurea (Silva Manso) Benth and Hook. F. ex S. Moore), 20\% - 62\% (Cybistax antisyphilitica (Mart.) Mart.) [Salomão 2002, Salomão et al. 2018] and 57\% - 76\% (Handroanthus impetiginosus (Mart. ex DC.) Mattos) [Martins et al. 2009]. For seeds of Handroanthus chrysotrichus (Mart. ex DC.) Mattos (Tresena et al. 2010), Jacaranda decurrens Cham. (Salomão 2002) and Tabebuia pentaphylla Helmsl (Aguiar et al. 2010), with mc of $4.0 \%, 5.2 \%$ and $7.1 \%$, respectively, there was no significant loss of germinability after freezing. The germinative percentages before and after freezing in LN were $87 \%$ - 82\% (H. chrysotrichus), $89 \%$ - 89\% (J. decurrens) and $89 \%-88 \%$ (T. pentaphylla).

Rapid freezing $\left(-263^{\circ} \mathrm{C} \cdot \mathrm{min}^{-1}\right)$ followed by slow thawing $\left(5^{\circ} \mathrm{C} \cdot \mathrm{min}^{-1}\right)$ increased germinative percentages of $P$. venusta seeds. Germination rates for seeds with $6.5 \% \mathrm{mc}\left(\mathrm{T}_{0}\right)$ was $88 \%$ before $(-\mathrm{LN})$ and $98 \%$ after $(+\mathrm{LN})$ cryopreservation. 
Seeds with $4.4 \mathrm{mc}\left(\mathrm{T}_{1}\right)$, presented $61 \%(-\mathrm{LN})$ and $95 \%$ $(+\mathrm{LN})$. For seeds dehydrated until they reached a mc of $3.8 \%\left(\mathrm{~T}_{2}\right)$, the germinative percentages were $78 \%(-\mathrm{LN})$ and $89 \%(+\mathrm{LN})$ (Figure 1).

\section{Conclusions}

The behavior of Pyrostegia venusta seeds after exposure to LN corroborates the adoption of cryopreservation for long-term conservation of this plant. For successful cryopreservation with high recovery rates it is recommended to desiccate seeds to $4.4 \%$ and $6.5 \%$ water content, submerge dry seeds rapidly in LN (estimated cooling rate of $\left.-263{ }^{\circ} \mathrm{C} . \mathrm{min}^{-1}\right)$ and to thaw them slowly at room temperature $\left(25 \pm 2{ }^{\circ} \mathrm{C}\right)$, at a cooling rate of $5{ }^{\circ} \mathrm{C} \mathrm{min}^{-1}$.

\section{Literature cited}

Aguiar, T. de. 2010. Conservação de sementes zigóticas e cultura in vitro de espécies de Tabebuia Gomes ex DC. (Bignoniaceae). Dissertação de Mestrado, Universidade Federal de Santa Catarina, Florianópolis.

Araújo, D.S. de, Luz, P.B. da Neves, L.G. \& Paiva Sobrinho, S. de. 2016. Seed cryopreservation of Passiflora species. Journal of Seed Science 38: 248-253.

Balešević-Tubic, S., Tatic, M., Đorđević, V., Nikolić, Z. \& Dukic, V. 2010. Seed viability of oil crops depending on storage conditions. Helia 33: 153-160.

Ballesteros, D., Walters, C. 2011. Detailed characterization of mechanical properties and molecular mobility within dry seed glasses: relevance to the physiology of dry biological systems. Plant Journal 68: 607-619.

Braga, K. de Q., Coimbra, M.C. \& Castro, A.H. F. 2015. In vitro germination, callus induction and phenolic compounds contents from Pyrostegia venusta (Ker Gawl.) Miers. Acta Scientiarum Biological Sciences 37: 151-158.

Brasil. Ministério da Agricultura, Pecuária e Abastecimento. 2009. Regras para análise de sementes. MAPA/ACS, Brasília. pp. 307-323.

Camarinha, C., Souza, D.R.de, Delgado, D. da R., Reis, L.A. \& Pantoja, S.C.de S. 2015. Levantamento de espécies da família Bignoniaceae ocorrentes na Universidade Castelo Branco, Campus Realengo - RJ. Revista Eletrônica de Biologia 8: 299-307.

Cerna, M., Valdivieso, P., Cella, R., Mátyás, B. \& Aucapiña, C. 2018. Cryopreservation of orchid seeds through rapid and step freezing methods. F1000Reserch 7: 209 .

Chmielarz P. 2009. Cryopreservation of dormant orthodox seeds of forest trees: Mazzard cherry (Prunus avium L.). Annals of Forest Science 66: 405
Colville, L. \& Pritchard, H.W. 2019. Seed life and food security. New Phytologist 224: 557-562.

Compêndio online Gerson Luiz Lopes. 2018. Pyrostegia venusta (Ker Gawl.) Miers cipó-de-são-João. Disponível em https://sites.unicentro.br/wp/manejoflorestal/8218-2/ (acesso em 10-XII-2018).

Ferrari, E.A.P., Colombo, R.C., Faria, R.T. de \& Takane, R.J. 2016. Cryopreservation of seeds of Encholirium spectabile Martius ex Schultes f. by the vitrification method. Revista Ciência Agronômica 47: 172-177.

Ferreira, D.T., Alvares, P.S.M., Houghton, P.J., \& Braz-Filho, R. 2000. Constituintes químicos das raízes de Pyrostegia venusta e considerações sobre a sua importância medicinal. Química Nova 23: 42-46.

Figueiredo, C.R., Matsuo, A.L., Pereira, F.V., Rabaça, A.N., Farias, C F., Girola, N., Massaoka, M. H., Azevedo, R.A., Scutti, J.A.B., Arruda, D.C., Silva, L.P., Rodrigues, E. G., Lago, J.H.G., Travassos, L.R. \& Silva, R.M.G. 2014. Pyrostegia venusta heptane extract containing saturated aliphatic hydrocarbons induces apoptosis on B16F10-Nex2 melanoma cells and displays antitumor activity in vivo. Pharmacognosy Magazine 10: 363-376.

Gabrielli, A.C. 1988 Anatomia da semente e das partes vegetativas em desenvolvimento de Pyrostegia venusta (Ker.) Miers (Bignoniaceae). Tese de Doutorado, Universidade Estadual de Campinas, Campinas.

González-Arnao, M.T., Martinez-Montero, M.E., Cruz-Cruz, C.A. \& Engelmann, F. 2014. Advances in cryogenic techniques for the long-term preservation of plant biodiversity. In: M.R. Ahuja \& K.G. Ramawat (eds.). Biotechnology and Biodiversity: Sustainable Development and Biodiversity 4. Springer International Publishing, Switzerland, pp. 129-170.

Hay, F.R. \& Probert, R.J. 2013. Advances in seed conservation of wild plant species: a review of recent research. Conservation Physiology 1:1-11.

Hortenci, L., Teixeira, R.C., Rogeri, P.K., Lopes, X.M., Valente-Neto, F., Koroiva, R. \& Scatollini, T. L.C. 2018. Biologia floral de Pyrostegia venusta (Bignoniaceae) em uma área de cerrado stricto sensu. Anais II Simpósio de Ecologia, pp. 19-23. Disponível em https://www.researchgate.net/publication/255484168 BIOLOGIA_FLORAL_DE_PYROSTEGIA_ VENUSTA_BIGNONIACEAE_EM_UMA_AREA_ DE_CERRADO_STRICTO_SENSU (acesso em 8-XII- 2018).

Jitsopakula, N., Thammasirib, K., Yukawa, T. \& Ishikawad. K. 2012. Effect of cryopreservation on seed germination and protocorm development of Vanda tricolor. ScienceAsia 38:244-249. 
Jordan, J.L., Jordan, L.S. \& Jordan, C.M. 1982. Effects of freezing to $-196{ }^{\circ} \mathrm{C}$ and thawing on Setaria lutescens seeds. Cryobiology 19: 435-442.

Kalaiselvi, R., Rajasekar, M. 7 Gomathi, S. 2017. Cryopreservation of Plant Materials - A Review. International Journal of Chemical Studies 5: 560-564.

Khanna, S., Jenkins, H., Bucalo, K., Determann, R.O., Cruse-Sanders, J.M. \& Pullman, G.S. 2014. Effects of seed cryopreservation, stratification and scarification on germination for five rare species of pitcher plants. CryoLetters 35: 29-39.

Mazur, P. 1984. Freezing of living cells: mechanisms and implications. American Journal of Physiology 47:125-142.

Martins, C. C., Silva, M.A.D. da \& Pinto, C. 2014. Armazenamento de sementes de ipê-amarelo-dobrejo (Handroanthus umbellatus (Sond.) Mattos. Bignoniaceae). Ciência Florestal 24: 533-539.

Martins, L., Lago, A.A. do, Andrade, A.C.S. de \& Sales, W.R.M. 2009. Conservação de sementes de ipê-roxo (Tabebuia impetiginosa (Mart. ex DC.) Standl.) em nitrogênio líquido. Revista Brasileira de Sementes 31: 71-76.

Michalak, M., Plitta, B.P. \& Chmielarz, P. 2013. Desiccation sensitivity and successful cryopreservation of oil seeds of European hazelnut (Corylus avellana). Annals of Applied Biology 163: 351-358.

Moreira, C.G., Carrenho, L.Z.B., Pawloski, P.L., Soley, B.S., Cabrini, D.A. \& Otuki, M.F. 2015. Pre-clinical evidences of Pyrostegia venusta in the treatment of vitiligo. Journal of Ethnopharmacology 168: 315-325.

Mostafa, N.M., El-Dahshan, O. \& Singab, A.N.B. 2013. Pyrostegia venusta (Ker Gawl.) Miers: A botanical, pharmacological and phytochemical Review. Medical and Aromatic Plants 2: 1-6.

Normah, M.N., Sulong, N. \& Reed, B.M. 2019. Cyopreservation of shoot tips of recalcitrant and tropical species: advances and strategies. Cryobiology, 87: 1- 4.

Oliveira, M.F. de \& Wendling, I.J. 2013. Uso e manejo de herbicidas em pastagens. Embrapa Milho e Sorgo, Documentos 165. Sete Lagoas.

Ortolani, F.A. 2018. Morfo-anatomia, citogenética e palinologia em espécies de ipês (Bignoniaceae). Disponível em http://hdl.handle.net/11449/102836. (acesso em 8-XII- 2018).

Panis, B. 2019. Sixty years of plant cryopreservation: from freezing hardy mulberry twigs to establishing reference crop collections for future generations. Acta Horticulturae 1234: 1-7.

Pereira, W.V.S., Faria, J.M.R., Tonetti, O.A.O. \& Silva, E.A.A. 2014. Loss of desiccation tolerance in Copaifera langsdorffii Desf. seeds during germination. Brazilian Journal of Biology 74: 501-508.
Plantamed. 2018. Pyrostegia venusta (Ker-Gawler) Miers. - cipó-de-são-joão. Disponível em http://www.lantamed. com.br./plantaservas/especies/Pyrostegia_venusta.htm. (acesso em 22-XII- 2018).

Renó, I.R., Moscheta, I.S. \& Braccini, A. de L. e. 2007. Morfo-anatomia do fruto e semente de amarelinho (Tecoma stans (L.) Kunth - Bignoniaceae). Revista Brasileira de Sementes 29: 18-30.

Rossatto, D.R. \& Kolb, R.M. 2010. Germinação de Pyrostegia venusta (Bignoniaceae), viabilidade de sementes e desenvolvimento pós-seminal. Revista Brasileira de Botânica 33:51-60.

Salomão, A.N. \& Santos, I.R.I. 2018. Criopreservação de fruteiras nativas. Embrapa Recursos Genéticos e Biotecnologia, Documentos 361. Brasília.

Salomão, A.N., Santos, I.R.I., José, S.C. B. R., Padilha, L. S. \& Mundim, R. C. 2018. Criopreservação de sementes de Cybistax antisyphilitica (Mart.) Mart. - Bignoniaceae. Embrapa Recursos Genéticos e Biotecnologia, Boletim de Pesquisa e Desenvolvimento 338. Brasília.

Salomão, A.N., Santos, I.R.I. \& Walter, B.M.T. 2015. Coleta e conservação de recursos genéticos ex situ: sementes de espécies florestais nativas. In: F. C. M. Piña-Rodrigues, M. B. Figliolia \& A. da. Silva (Org.). Sementes florestais tropicais: da ecologia à produção. $1^{\text {ed }}$. Londrina. Abrates - Associação Brasileira de Tecnologia de Sementes, pp. 167-178.

Salomão, A.N. \& Fujichima, A.G. 2002. Respostas de sementes de Tabebuia aurea (Silva Manso) Benth. \& Hook. F. ex S. Moore (Bignoniaceae) à dessecação e ao congelamento em temperaturas subzero. Embrapa Recursos Genéticos e Biotecnologia, Circular Técnica 76. Brasília.

Salomão, A.N. 2002. Tropical seed species' responses to liquid nitrogen exposure. Brazilian Journal of Plant Physiology 14: 133-138.

Sano, N., Rajjou, L., North, H.M., Debeaujon, I., MarionPoll, A. \& Seo, M. 2016. Staying alive: molecular aspects of seed longevity. Plant Cell Physiology 57: 660-674.

Santana, D.G.de \& Ranal, M.A. 2004. Análise da germinação: um enfoque estatístico. Editora Universidade de Brasília, Brasília.

Santos, I.R.I. \& Salomão, A.N. 2017. In vitro Germination of zygotic embryos excised from cryopreserved endocarps of queen palm (Syagrus romanzoffiana (Cham.) Glassman). In Vitro Cellular \& Developmental Biology - Plant 53: 418-424.

Santos, I.R.I., Salomão, A.N., Vargas, D.P., Silva, D.P.C., Nogueira, G.F., Carvalho, M.A.F. \& Paiva, R. 2013. Situación actual y perspectivas de la investigación en crioconservación de recursos fitogenéticos en Brasil. In: T. González-Arnao, F. Engelmann (eds.). Crioconservación de plantas en América Latina y el Caribe. San José. pp. 84-104. 
Santos, S.P. dos. 2016. Germinação, estaquia e biometria de sementes de Pyrostegia venusta (Ker Gawl.) Miers (cipó de São João). Dissertação de Mestrado, Universidade Federal da Bahia, Vitória da Conquista.

Scalon, S.P.Q., Vieira, M.C., Lima, A. A., Souza, C. M. \& Mussury, R.M. 2008. Tratamentos pré-germinativos e temperaturas de incubação na germinação de cipó de São João [Pyrostegia venusta (Ker Gawl.) Miers] Bignoniaceae. Revista Brasileira de Plantas Medicinais 10: 37-42.

Shankaralingappa, Y.H., Vasugi, C. \& Naik, L.B. 2019. Ultra dry storage - a cost effective method for conservation of germplasm and comercial seeds of papaya. Indian Journal of Horticulture 76: 423-429.

Tarré, E., Pires, B.B.M., Guimarães, A.P.M., Carneiro, L.A., Forzza, R.C. \& Mansur, E. 2007. Germinability after desiccation, storage and cryopreservation of seeds from endemic Encholirium Mart. ex Schult. \& Schult. f. and Dyckia Schult. \& Schult. f. species (Bromeliaceae). Acta Botanica Brasilica 21: 777-783.
Tresena, N. de L., Cavalcanti-Mata, M.E.R.M., Duarte, M.E.M. \& Moraes, A.M.de. 2010. Determinação do teor de água limite para crioconservação das sementes de ipê amarelo (Tabebuia chrysotrica (Mart. Ex. DC.) Standl.). Cerne 16: 171-175.

Veloso, C.C., Cabral, L.D.M., Franqui, L.S., Dias, D.F., Santos, M.H. dos, Soncini, R. \& Giusti-Paiva, A. 2010. Pyrostegia venusta attenuate the sickness behavior induced by lipopolysaccharide in mice. Journal of Ethnopharmacology 132:355-358.

Wu, G., Jaganathan, G.K., Song, D. \& Liu, B. 2017. Cryopreservation of selected physical dormant species with special focus on dormancy breaking time. Res. J. Seed Sci., 10: 38-42.

Zhang, J., Wang, H., Liao, S. \& Cui, K. 2019. Appropriate ultra-low seed moisture content stabilizes the seed longevity of Calocedrus macrolepsis, associated with changes in endogenous hormones, antioxidant enzymes, soluble sugars and unsaturated fatty acids. New Forests 50: $455-468$. 